\title{
Impact of fertility variation on genetic diversity and phenotypic traits in second generation seed production areas and clonal seed orchards of Eucalyptus camaldulensis
}

\author{
Suraj, P.G. ${ }^{1}$, Nagabhushana, K. ${ }^{1}$, Kamalakannan, R. ${ }^{1}$ and M. Varghese ${ }^{1 *}$ \\ ${ }^{1}$ ITC Life Sciences and Technology Centre (LSTC), Bengaluru 560 058, India \\ * Corresponding author: Mohan Varghese, mvarghese1@rediffmail.com; Mohan.Varghese@itc.in
}

\begin{abstract}
Fertility and gene diversity were estimated in three second generation $\left(\mathrm{F}_{2}\right)$ seed stands (SPA 1-3) and two clone trials (CSO $1 \& 2$ ) of Eucalyptus camaldulensis to assess the impact on seed crop. $F_{2}$ seedlots were evaluated in comparison to native provenances, ten commercial clones and interspecific hybrids at diverse sites. SPA $1 \& 2$ were genetic gain trials of five first generation $\left(F_{1}\right)$ orchard seedlots, SPA 3 a plantation of one $F_{1}$ orchard seedlot, and CSOs were clone trials of 21 commercial clones established at two contrasting sites. Fertility variation, as indicated by sibling coefficient, was high $(\psi, 9-14)$ in the SPAs as only about $26 \%$ trees were fertile compared to $81 \%$ trees in CSOs. Effective population size was higher in SPA 1 and $2\left(N_{s^{\prime}}, 95\right.$ and 74 , respectively) than SPA $3\left(N_{s}=39\right)$. Fertility was highly skewed in CSO 2 resulting in low effective population size $\left(N_{s}=\right.$ 2) compared to CSO $1\left(N_{s}=11\right)$. Constant seed collection enabled 3-fold increase in relative population size and $22 \%$ higher predicted gene diversity in CSO 2. Genetic diversity $\left(H_{e}\right)$ estimated using SSR markers was higher in SPA $1 \& 2$ and native provenances (NAT), compared to SPA 3 and CSO 1, whereas CSO 2 and clones had lower values. There was a high positive correlation between estimated $H_{e}$ and predicted gene diversity values of SPAs and CSOs. $H_{e}$ was positively correlated to mean field survival and negatively correlated to kraft pulp yield (KPY), evaluated at three years in progeny trials across three locations. Number of alleles per locus was higher in SPAs and native provenances compared to CSOs and clones. Discriminant principal component analysis clustered CSO, NAT and SPA seedlots in different groups while commercial E. camaldulensis clones clustered close to NAT. Multilocus outcrossing rate was generally high $\left(t_{m^{\prime}}, 91-100 \%\right)$, though selfing was observed in two families of SPA 3 and CSO 2. Selected interspecific hybrid families of commercial E. camaldulensis clones (with E. urophylla and E. pellita) evaluated at two of the sites had higher $H_{e}$ and KPY than clones at three years.
\end{abstract}

Keywords: genetic improvement, mating system, seed orchard, provenance, hybrids, progeny trial, gene diversity, molecular markers, pulp yield, inbreeding

\section{Introduction}

Eucalyptus camaldulensis Dehnh is widely cultivated in India as it is well adapted to tropical regions with hot dry summer and low rainfall. Native provenances of E. camaldulensis like Kennedy River, Laura River, Morehead River and Petford were identified to give higher productivity than the Indian eucalypt land race (Varghese et al., 2000). Commercial clones of E. camaldulensis developed from selections in provenance trials (Kulkarni, 2014) helped to enhance productivity of eucalypt plantations. Since majority of eucalypt planting in India is in farmlands with varied soil, climate and management practices, the best suited clone may not be deployed at each site. A few clones are often planted over vast areas resulting in outbreak of pests and diseases, leading to elimination of some best performing clones (Krishnakumar et al., 2014). A breeding program for $E$. camaldulensis was implemented in southern India with seed collections from over 500 selected trees of 11 native Australian provenances (Doran et al., 1996). Improved seed was supplied to farmers from first generation unpedigreed and pedigreed seedling seed orchards (Kamalakannan et al., 2007; Krishnakumar et al., 2014). Many of these plantations have been used to produce seeds to meet the large planting stock requirement of farm forestry. Clonal plantations are also used as source of seed to replace the low yielding eucalypt land race. These plantations do not conform to typical seed orchards that package genes and generate improved seed after a generation of breeding. Good quality seed from proven source can enhance productivity and genetic base of planting stock. In tree improvement programs clonal seed orchards (CSO) are expected to 
give higher gain than seed production area (SPA), and clonal plantation of best suited clone can give enhanced yield at a given site (Griffin, 2014). The gain however depends on the degree of outcrossing among trees and adaptability of genetic material to the deployed site (Burgess et al., 1996). Seed stands give comparatively lower gain but maintain higher diversity and hence offer a conservative but safe strategy (Lindgren, 2003). A study was therefore taken up to evaluate the genetic quality of seed obtained from seed stands (referred as SPA) and commercial clone trials (referred as CSO), in comparison to native provenances, commercial clones and their interspecific hybrids ( $E$. camaldulensis $x$ E. urophylla/E. pellita).

Genetic diversity is a prerequisite for genetic improvement of a species. Davidson (1998) observed that "eucalypt improvement in India has remained weakly supported from the point of view of domestication", and emphasised the need to maintain sufficient diversity for success of future generations. Qualitative and quantitative knowledge of genetic diversity provides a scientific basis for better management of genetic resources in forest tree species (Poltry et al., 2003). A detailed understanding of genetic diversity available in breeding populations is necessary to enhance gain in advanced generations and maintain diversity in planting stock (Johnson et al., 2001). Molecular markers are valuable tools used for characterization and evaluation of genetic diversity within and between populations (Hou et al., 2005), and different levels of improvement (Lyngdoh et al., 2013). Among these markers, microsatellites (simple sequence repeats: SSRs) are widely used due to advantages like high levels of polymorphism, co-dominant nature and high reproducibility (Sumathi and Yasodha, 2014).

It is necessary to keep track of genetic diversity of planting stock along with the improvement obtained in wood traits (Jones et al., 2006) for sustaining productivity with domestication. This involves a detailed analysis of the variation in genetic and phenotypic traits with genetic improvement. In a recent study, seed lots collected from second generation SPAs and clone trials (CSOs) were seen to be more productive than native provenance seed (NAT) in progeny trials evaluated at three sites in southern India (Varghese et al., 2017). The study also revealed that site effect on growth, kraft pulp yield (KPY) and wood density was greater than that of planting stock (between different sources - native provenance, SPA, CSO and clone). Though clones had slightly higher pulp yield, low adaptability of some clones resulted in poor overall survival at three sites. To reduce mortality and maximize wood production it is necessary to address the growth limiting factors by understanding the adaptability of planting material, and soil moisture status of different sites (White et al., 2014). Genetic gain achieved in breeding programs is often associated with loss in genetic diversity, which is essential for ensuring fitness of the planting stock (Ivetić et al., 2016). Optimizing these traits is a key factor in determining the genetic quality of seed crop (Funda and ElKassaby, 2012). Silva et al. (2018) emphasised the need to maintain adequate effective population size in breeding populations, to minimise productivity loss due to inbreeding, when high selection intensity is used for enhancing gain. They suggested using quantitative analysis and genetic marker based estimation of genetic variation in orchards, for balancing gain and diversity in breeding programs. Fertility of parent trees plays a major role in determining the diversity of progeny. Fecundity of orchard trees can be used to predict gene diversity of seed crop and relatedness among progeny, by estimating fertility variation and co-ancestry (Lindgren and Mullin, 1998). Fertility based gene diversity estimates have been used to determine overall benefit from seed orchards (Kang et al., 2001; Kamalakannan et al., 2007), while molecular markers have been widely used to evaluate genetic structure and diversity of seed orchards (Chezhian et al., 2010; Jones et al., 2006). The correlation between predicted gene diversity, and genetic diversity estimated from molecular markers (Kamalakannan et al., 2009) is not well evaluated. Management strategies like individual tree seed collection can be used to reduce the impact of fertility variation and enhance predicted gene diversity of seed crop (Kang et al., 2003).

Estimation of genetic diversity loss from native base population to breeding and production populations, in relation to gain obtained (Silva et al., 2018), would be vital for scientific domestication of a species. Mating system may vary in different populations which can have a significant impact on allelic frequency and performance of the crop (Rao and Hodgkin, 2002). For maintaining genetic diversity in an orchard it is necessary to optimize (Danusevicius and Lindgren, 2010) the number of genetically unique individuals that contribute to gene pool. The number of individuals required to maximise gain for a given diversity can be optimised (Funda et al., 2009) if the relationship between these factors is known. This paper describes the fertility status and predicted gene diversity in second generation E. camaldulensis SPAs and clonal orchards, and their validation using molecular markers. The study aims to investigate the mating pattern and extent of inbreeding in second generation populations, and test the hypothesis that genetic diversity of seed crop has a significant impact on phenotypic traits of progeny.

\section{Materials and Methods}

Individual tree seed collection was made from 7-11 trees (or clones) each in three SPAs (SPA 1-3) and two clone trials (CSO 1-2) located in southern India at five years of age (Table 1 and 2). Fecundity of trees was estimated before seed collection as described by Varghese et al. (2003). SPA $1 \& 2$ were thinned genetic gain trials of bulk seedlots from five first generation $\left(F_{1}\right)$ seedling orchards established as per a breeding program for $E$. camaldulensis (Doran et al., 1996) and SPA 3 was a thinned plantation of one $\mathrm{F}_{1}$ orchard seed lot maintained for seed production. The clonal seed orchards were replicated clone trials of 21 commercial clones at two diverse sites (CSO 1 - in red soil and CSO 2 - in black soil). Fertility variation and predicted gene diversity were computed for the stands based on fecundity estimates of parent trees. Progeny trials comprising 48 openpollinated seedlots of three SPAs and two CSOs, and 183 native provenance families (Laura river, Kennedy river, Morehead river 
and Petford) were evaluated at three diverse sites. Phenotypic traits like growth, survival (\%) and pulp yield (\%) were evaluated in these seedlots at three years, in an earlier study along with 10 commercial clones as control (Varghese et al., 2017). Four superior interspecific hybrid families were also used for comparison at three years from hybrid family trials (out of 16 control crossed families of commercial E. camaldulensis clones with E. urophylla/E. pellita), tested along with the E. camaldulensis seedlots at two locations (Kamalakannan et al., 2011). Data analysis of E. camaldulensis progeny trials using Genstat 17 (VSN International, Hemel Hempstead, UK) is explained by Varghese et al. (2017). Two phenotypic traits namely mean survival rate (\%) and kraft pulp yield (KPY) reported (across three sites) in that study, were used to evaluate the impact of genetic diversity on variability of the traits.

\section{Fertility evaluation in orchards}

Total fertility of a tree $\left(\rho_{1}\right)$ was taken as the average of the male and female fertilities of each tree. When equal number of fruits is collected from each tree, the female fertility is assumed to be constant, equal to $1 / N$, where $N$ is the census number of trees (genotypes) in the stand. Constant seed collection (Kang et al., 2003) was made in the orchards since fecundity varied among trees, by collecting same quantity of seed (about $5 \mathrm{~g}$ seed) from each tree to equalize the maternal fertility and avoid over representation of high fertility trees.

\section{Dynamics of seed orchards}

Sibling coefficient $(\Psi)$ was calculated from the number of genotypes in the stand $(N)$ and individual fertility $\left(\rho_{1}\right)$ of each tree to describe fertility variation among the trees (Kang et al., 2001),

$\psi=N \sum_{i=1}^{N} p_{i}^{2}$

Group coancestry $(\Theta)$ is the probability that two genes taken at random from the gene pool of the expected seed crop will be identical by descent. Since the current plantations originated from parent orchards established from a wide base of more than 500 trees of 11 native provenances (Kamalakannan et al., 2007) and several unrelated clones the trees in SPAs and CSOs were considered to be non-related and non-inbred. All pairwise coancestries will thus be equal to zero and all self-coancestries equal to 0.5 and the $\Theta$ can be calculated (Kang and Lindgren, 1999) as

$$
\Theta=0.5 \sum_{i=1}^{N} p_{i}^{2},
$$

where $\rho_{1}$ is the probability that genes sampled at random from the gamete pool originate from genotypes $i$. When the seed bearing trees are considered non-inbred and non-related, effective population size (status number) can be calculated (Lindgren and Mullin, 1998) as

$$
N_{s}=\frac{1}{\sum_{i=1}^{N} p_{i}^{2}}
$$

where $\rho_{1}$ is the contribution from individual genotype $i$ to the gamete pool and $N$ the census number of trees in the orchard. Relative status number $\left(N_{r}\right)$ was used to compute the proportion of the effective number of trees contributing to random mating with the actual number of genotypes retained in the stand,

$$
N_{r}=\frac{N_{s}}{N}
$$

Expected gene diversity $(G D)$ was estimated in terms of group coancestry (Kang et al., 2003). Since the originating reference population (which is the natural forest from which plus tree seeds were obtained for developing the first generation orchards and clones) is assumed to have zero group coancestry, gene diversity is calculated based on the increase in $\Theta(G D$ $=1-\Theta)$.

\section{Genotypic study}

Leaf samples were collected from 25-35 randomly selected seedlings each of open-pollinated seed sources, namely native provenances (NAT), three SPAs and two CSOs. Ten commercial E. camaldulensis clones and 14 bulked seedlings from four control crossed inter-specific hybrid families (Table 1) were also sampled for estimating genetic diversity $\left(H_{e}\right)$. Leaf samples were collected from 10-12 progenies from three tested families each of second generation SPAs and CSOs for mating system analysis. Leaf samples collected from young leaves were powdered using liquid nitrogen and stored in $-80^{\circ} \mathrm{C}$. Genomic DNA was isolated from the young leaf tissues using the modified CTAB protocol described by Hendre et al. (2012). Twelve polymorphic SSR primers were selected for marker analysis by capillary genotyping adopting two-tier PCR system described by Nagabhushana et al. (2017).

\section{Statistical analysis}

Genotypic data generated were analyzed and compiled using Peak Scanner V 1.0 software (Applied Biosystems, Foster City, USA) for determining the exact allele size. Allele sizes for each SSR locus were used for genetic analysis using Cervus 3.0 software (Kalinowski et al., 2007), for estimating the number of alleles $\left(N_{a}\right)$, expected heterozygosity $\left(H_{e}\right)$ and polymorphism information content (PIC). Using the software GenAIEx V6.5 (Peakall and Smouse, 2012), the hierarchical partitioning of genetic variation within and among second generation seedlots (SPAs and CSOs) was estimated by Analysis of Molecular Variance (AMOVA) with 1000 permutations. Genetic relationships among individuals were analyzed by discriminant 
analysis of principal components (DAPC) using a multivariate ordination method in the R package ADEGENET (Jombart, 2008). Outcrossing rate was estimated in three families each of SPAs and CSOs using the multilocus estimation model of MLTR 2.3 , using 1000 bootstraps. Multilocus $\left(t_{m}\right)$ and single locus $\left(t_{s}\right)$ outcrossing rate, bi-parental inbreeding $\left(t_{m}-t_{s}\right)$ and multilocus paternity correlation $\left(r_{p}\right)$ were estimated in open pollinated families (Ritland, 2002).

Table 1

Genetic material used for the study

\begin{tabular}{|c|c|c|c|}
\hline Group & Type & Source & Seedlots/Clones \\
\hline$E c(\mathrm{NAT})$ & Native seedlot & $\begin{array}{l}\text { Kennedy River, Laura River, } \\
\text { Morehead River \& Petford } \\
\text { provenances }\end{array}$ & $183(\mathrm{~F})$ \\
\hline$E c$ (SPA 1-3) & $2^{\text {nd }}$ Gen seed crop & $2^{\text {nd }}$ Generation SPA & $31(\mathrm{~F})$ \\
\hline$E c(\mathrm{CSO} 1-2)$ & CSO seed crop & Clone trial of Commercial clones & $17(\mathrm{~F})$ \\
\hline Ec Clones & Commercial clones & Selections from provenance trials & $10(\mathrm{C})$ \\
\hline Ec Hybrids & Hybrid seed lot & $E c$ clones $\mathrm{x} E \mathrm{u} / \mathrm{Ep}$ & $4 \quad(\mathrm{~F})$ \\
\hline \multicolumn{4}{|c|}{$\begin{array}{l}\text { Ec - E.camadulensis } ; \mathrm{SPA}-\text { Seed production area } ; \mathrm{CSO}-\text { Clonal seed orchard } ; \mathrm{Eu}-E \text {. } \\
\text { urophylla } ; \text { Ep }- \text { E. pellita } ; \mathrm{F} \text { - Family seedlots; } \mathrm{C}-\text { Clones }\end{array}$} \\
\hline
\end{tabular}

Table 2

Fertility variation and predicted gene diversity of progeny in SPA and CSO

\begin{tabular}{|c|c|c|c|c|c|c|c|}
\hline Orchard & $\begin{array}{c}\text { No. of } \\
\text { trees/ } \\
\text { Clones }\end{array}$ & $\begin{array}{c}\text { Fertile } \\
\text { trees } \\
(\%)\end{array}$ & $\begin{array}{c}\text { Fruits/ } \\
\text { tree }\end{array}$ & $\Psi$ & $N s$ & $\begin{array}{c}\text { Trees (\%) } \\
\text { contributing } \\
80 \% \text { fertility }\end{array}$ & $\begin{array}{c}G D \\
\text { (predicted) }\end{array}$ \\
\hline SPA-1 & 1029 & 26 & 638 & 10.84 & 94.9 & 8.7 & 0.995 \\
\hline SPA-2 & 1050 & 23 & 984 & 14.14 & 74.26 & 7.1 & 0.993 \\
\hline SPA-3 & 369 & 26 & 136 & 9.40 & 39.25 & 9.5 & 0.987 \\
\hline CSO-1 & 21 & 81 & 1518 & 1.95 & 10.8 & 67 & 0.966 \\
\hline CSO-2 & 21 & 81 & $\begin{array}{c}14330 \\
\left(1471^{*}\right)\end{array}$ & 10.59 & 1.98 & 9.5 & 0.915 \\
\hline
\end{tabular}

* Excluding two high fertility clones

\section{Results}

\section{Fertility variation in SPAs and CSOs}

Fertility was low in the SPAs with 23-26 \% fertile trees (Table 2). In the CSOs $81 \%$ trees were fertile, but fruit set was very low in four clones in both clone trials (data not shown). Fertility variation was very high in SPA $1 \& 2(\Psi, 11 \& 14)$ as the stocking $(N)$ was more than 1000 trees. Since $74 \%$ of the 369 standing trees in SPA 3 had not flowered, sibling coefficient was high $(\psi=9.5)$ indicating high genetic drift. The two CSOs located at two contrasting sites differed considerably in fertility. Two clones in CSO 2 had unusually high fecundity contributing almost $80 \%$ of the flowers and fruits in the stand. Sibling coefficient was very low $(\Psi=1.95)$ in CSO 1 as fertility variation was low among clones. Among the clonal stands CSO 1 had high representation (67\% trees contributed $80 \%$ fruits) of parent trees in the seed crop, as fertility was quite balanced compared to CSO 2 . The mean number of fruits produced per tree was higher in CSOs and fertility was less variable in the clones as indicated by the low sibling coefficient in CSO 1. In CSO 2, the trend was almost the same with the exception of two clones that dominated the seed crop due to unusually high fecundity (average 14330 fruits/tree). Since there were many parental genotypes in the SPAs and substantial variation in fecundity, fertility variation was high with less than $10 \%$ trees contributing $80 \%$ fruits in each stand.

\section{Effective population size $\left(N_{s}\right)$ and predicted gene diversity $(G D)$}

SPAs had higher effective population size $\left(N_{s^{\prime}} 39-95\right)$ than clonal stands (Table 2) since there were more genotypes contributing to seed crop. Since SPA $1 \& 2$ had more than 1000 trees, $N_{s}$ was almost twice as that of SPA 3. CSO 2 had very low $N_{s}$ (1.98) due to very high contribution from two clones resulting in 27 $\%$ lower predicted GD than CSO 1 and just over $9 \%$ trees contributing $80 \%$ of the seed crop. Since fecundity was more balanced in CSO 1, $67 \%$ trees from 13 clones (data not shown) contributed the same proportion of fruits ( $80 \%)$ produced by just two clones in CSO 2. This imbalance and low gene diversity in CSO 2 was moderated in the seed crop by resorting to constant seed collection from 7 mother trees (7 different clones). Constant seed collection from mother trees enabled $66 \%$ reduction in sibling coefficient resulting in 3 -fold increase in relative contribution and $22 \%$ enhancement in predicted gene diversity of CSO 2 (Table 3). Though CSOs had lower predicted gene diversity constant seed collection enabled increase in predicted GD especially in CSO 2.

Table 3

Dynamics of CSOs in different fertility situations

\begin{tabular}{|l|l|l|l|l|l|l|}
\hline Trait & \multicolumn{2}{|c|}{ Varying fertility } & \multicolumn{2}{c|}{ Equal fertility } & \multicolumn{2}{c|}{ Constant seed collection } \\
\hline & CSO 1 & CSO 2 & CSO 1 & CSO 2 & CSO 1 & CSO 2 \\
\hline$\Psi$ & 1.95 & 10.59 & 1.0 & 1.0 & 1.41 & 3.57 \\
\hline$N_{r}$ & 0.51 & 0.09 & 1.0 & 1.0 & 0.71 & 0.28 \\
\hline$\Theta$ & 0.047 & 0.252 & 0.024 & 0.024 & 0.034 & 0.085 \\
\hline$G D$ & 0.953 & 0.748 & 0.976 & 0.976 & 0.966 & 0.915 \\
\hline
\end{tabular}
diversity

\section{Genetic diversity and phenotypic traits}

Genetic diversity $\left(H_{e}\right)$ was highest in SPA 1 seedlot $(0.70)$, followed by SPA 2 (0.69) (Table 4). Progeny of SPA 3, NAT and CSO 1 had the same $H_{e}(0.68)$ value, whereas it was lower in CSO 2 (0.65) and commercial clones (0.54). The allelic diversity was highest in SPA 2 (7.4 alleles per locus) and lowest in commercial clones (4.5 alleles per locus). Hybrids had higher $H_{e}(0.71)$ and 
PIC (0.65) than E. camaldulensis seedlots and clones and more alleles than CSO seedlots and clones.

AMOVA showed $78 \%$ variation within E. camaldulensis populations (Table 5), indicating high levels of variation within each population. Principal coordinate analysis (PCoA) based on pairwise genetic difference, indicated separate groupings for native seedlots (NAT), SPAs and CSOs (Figure 1). Two-dimensional discriminant analysis of principal components, clustered the E. camaldulensis populations in three different groups SPAs, CSOs and NAT; with commercial clones falling in the same group as NAT. However, there was some overlap of SPA progeny with CSO and NAT clusters. In general, all individuals were differentiated by their source of origin.

Table 4

Genetic diversity and mean phenotypic traits of E. camaldulensis and hybrids

\begin{tabular}{lllllcl}
\hline Taxa & $N$ & $N_{a}$ & $\boldsymbol{H}_{e}$ & PIC & $\begin{array}{c}\text { Survival } \\
(\%)\end{array}$ & $\begin{array}{c}\text { KPY } \\
(\%)\end{array}$ \\
\hline NAT & 25 & 7.07 & 0.68 & 0.63 & 72 & 45.0 \\
SPA 1 & 32 & 7.13 & 0.70 & 0.64 & 76 & 44.8 \\
SPA 2 & 35 & 7.38 & 0.69 & 0.64 & 74 & 45.1 \\
SPA 3 & 31 & 6.75 & 0.68 & 0.63 & 66 & 44.7 \\
CSO 1 & 33 & 5.94 & 0.68 & 0.62 & 65 & 45.3 \\
CSO 2 & 34 & 5.88 & 0.65 & 0.60 & 54 & 45.1 \\
Clones & 10 & 4.50 & 0.54 & 0.53 & 50 & 45.5 \\
\hline$A v S E D$ & - & - & - & & 6 & 0.22 \\
\hline Hybrids & 14 & 6.65 & 0.71 & 0.65 & $90^{\sharp}$ & $47.7^{\sharp}$ \\
\hline
\end{tabular}

$N$ : Number of progenies, $N_{a}:$ Number of alleles, $H_{e}$ : Expected heterozygosity

(Diversity index), PIC: Polymorphism information content $*$ Mean values of

E. camaldulensis traits across three sites (from Varghese et al., 2017) \# Mean values of four hybrid families at two sites.

Table 5

Estimates of AMOVA in E. camaldulensis SPA and CSO seedlots

\begin{tabular}{lllllc}
\hline Source & df & MS & Est. Var. & \% variation & P \\
\hline Among Pops & 4 & 74.344 & 4.919 & $22 \%$ & $<0.01$ \\
Within Pops & 55 & 17.822 & 17.822 & $78 \%$ & $<0.01$ \\
Total & 59 & & 22.740 & $100 \%$ & \\
\hline
\end{tabular}

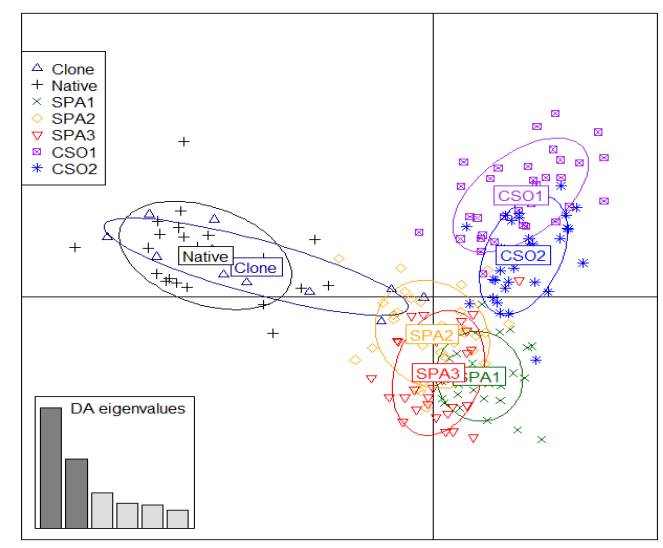

Figure 1

Discriminant analysis of principal components of E. camaldulensis populations (Native provenances, SPAs, CSOs and clones) constructed using 12 microsatellite markers.
Mean survival (\%) and pulp yield (KPY \%) of E. camaldulensis seedlots and clones (across three sites - obtained from an earlier study), and four hybrid families (from two of the sites) at three years are listed in Table 4. Two second generation SPA seedlots (SPA 1\&2) had significantly higher mean survival than clones and $\mathrm{CSO} 2$ seed lot at three sites, whereas the hybrid families had better survival than $E$. camaldulensis clones and seedlots at two experimental sites (Table 4). E. camaldulensis clones had more or less similar pulp yield as the seedlots but hybrids had $2 \%$ higher absolute pulp yield than clones at the respective sites (data not shown).

Genetic diversity $\left(H_{e}\right)$ showed positive correlation with survival rate and negative relationship with pulp yield in $E$. camaldulensis (Figure 2). There was also a very high positive correlation between predicted gene diversity (based on fertility variation) and genetic diversity $\left(H_{e}\right)$ value estimated using SSR markers in SPA and CSO seedlots of E. camaldulensis (Figure 3).

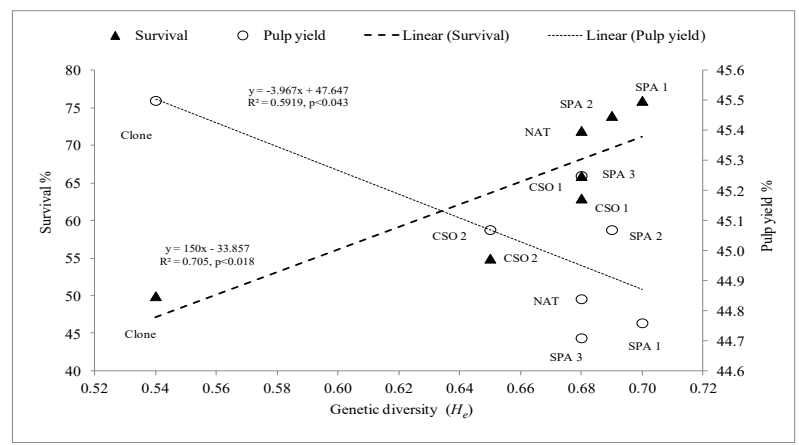

Figure 2

Relationship of genetic diversity $\left(H_{e}\right)$ with phenotypic traits survival (\%) and pulp yield (\%) in E. camaldulensis.

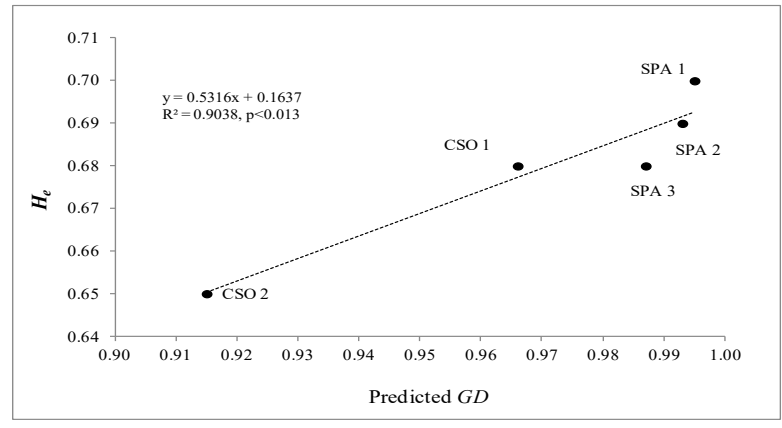

Figure 3

Relationship of predicted gene diversity $(G D)$ with estimated genetic diversity $\left(H_{e}\right)$ in SPA and CSO progeny of E. camaldulensis

\section{Mating system}

The MLTR estimates for single and multi-locus outcrossing rates and bi-parental inbreeding for fifteen families (3 each of SPAs and (SOs), and multilocus paternity correlation for each orchard are presented in Table 6. Outcrossing rate was high in all families assayed from SPA $1 \& 2$ and CSO 1 with $t_{m}$ values 
ranging from 0.91-1.0. Self-pollination was observed in one family each of SPA 3 (31\%) and CSO 2 (23\%) whereas other families in these stands were outcrossed. Even though outcrossing rate was high in SPA 2 and CSO 1, bi-parental inbreeding was observed in one family each in these stands. All families of CSO 2 had 3-6 \% bi-parental inbreeding compared to other seedlots. Correlated paternity was generally low with 6-10\% full sibs in the SPAs and 2-6\% full sibs in CSOs.

Table 6

Estimates of single and multi-locus outcrossing rate in SPA and CSO families

\begin{tabular}{|c|c|c|c|c|c|}
\hline Family & $N$ & $t_{m}$ & $t_{s}$ & $t_{m}-t_{s}$ & $r_{p}$ \\
\hline \multicolumn{6}{|l|}{ SPA 1 } \\
\hline Family 1 & 10 & $1.00(0.001)$ & $1.00(0.079)$ & 0.00 & \multirow{3}{*}{0.059} \\
\hline Family 2 & 10 & $1.00(0.001)$ & $1.00(0.085)$ & 0.00 & \\
\hline Family 3 & 12 & $1.00(0.001)$ & $1.00(0.135)$ & 0.00 & \\
\hline \multicolumn{6}{|l|}{ SPA 2} \\
\hline Family 4 & 12 & $1.00(0.004)$ & $0.86(0.26)$ & 0.18 & \multirow{3}{*}{0.096} \\
\hline Family 5 & 11 & $0.91(0.1)$ & $0.90(0.164)$ & 0.01 & \\
\hline Family 6 & 11 & $0.99(0.029)$ & $1.00(0.146)$ & 0.01 & \\
\hline \multicolumn{6}{|l|}{ SPA 3} \\
\hline Family 7 & 10 & $0.69(0.284)$ & $0.87(0.251)$ & -0.17 & \multirow{3}{*}{0.081} \\
\hline Family 8 & 10 & $1.00(0.001)$ & $1.00(0.143)$ & 0.00 & \\
\hline Family 9 & 11 & $1.00(0.008)$ & $1.00(0.313)$ & 0.00 & \\
\hline \multicolumn{6}{|l|}{ CSO 1 } \\
\hline Family 10 & 10 & $0.97(0.06)$ & $0.62(0.156)$ & 0.35 & \multirow{3}{*}{0.024} \\
\hline Family 11 & 11 & $1.00(0.006)$ & $1.00(0.11)$ & 0.00 & \\
\hline Family 12 & 12 & $0.99(0.09)$ & $1.00(0.207)$ & 0.01 & \\
\hline \multicolumn{6}{|l|}{$\mathrm{CSO} 2$} \\
\hline Family 13 & 12 & $1.00(0.003)$ & $0.94(0.109)$ & 0.06 & \multirow{3}{*}{0.061} \\
\hline Family 14 & 11 & $0.77(0.276)$ & $0.74(0.276)$ & 0.03 & \\
\hline Family 15 & 11 & $1.00(0.001)$ & $0.94(0.079)$ & 0.06 & \\
\hline
\end{tabular}

\section{Discussion}

\section{Variation in genetic diversity with genetic improvement}

Genetic improvement programs are expected to generate superior planting stock compared to native stands and unimproved land race. Breeding plans are developed to produce genetic gain and conserve genetic diversity by controlling relatedness among deployed individuals. Loss of diversity and increase in relatedness are expected in advanced stages of improvement (Johnson et al., 2001). As relatedness increases beyond a certain point, depending on deviation from random mating, the expected benefits may not be obtained (Kamalakannan et al., 2016). Inbreeding can build up if seeds from very few mother trees are used to establish a stand, and next generation will be derived from mating between close relatives. Adequate representation from different families will be needed for production of outcrossed seed. Increase in genetic gain is expected with progression from native provenance to seed production area (SPA) and clonal seed orchard (CSO), but the associated loss in diversity is often not evaluated (Lyngdoh et al., 2013). In the current study, genetic diversity $\left(H_{e}\right)$ of SPA 1 was $3 \%$ higher than that of native (NAT) seedlots, whereas ten E. camaldulensis clones of $0.7 \%$ higher absolute pulp yield had almost $30 \%$ lower $H$ than SPA 1. Deployment of ten E. camaldulensis clones of low genetic diversity $\left(H_{e}=0.54\right)$ across three diverse sites was however associated with almost $52 \%$ lower mean survival than SPA 1 seedlot. While $H_{e}$ decreased from SPA $1(0.70)$ to CSO 2 (0.65) survival rate dropped from 76 to 54 $\%$, and survival was lowest in clones (50\%) with least genetic diversity. Inbreeding in forest trees is generally associated with reduced growth and survival, which becomes prominent with age and environmental stress (Liby et al., 1981; Williams and Savolainen., 1996). Breeding populations generally have higher diversity than native base population when mating occurs between different provenances (Lefevre, 2004). Compared to seed crops, deployment of clones will reduce genetic and allelic diversity, and the number of unique genotypes (Ingvarsson and Dahlberg, 2018).

First generation SPAs of E. camaldulensis were established in southern India with a broad genetic base (Krishnakumar et al., 2014), which enabled a wide range of traits to carry forward in next generation. This study revealed that that there was no loss in genetic diversity when genetic gain trials of $F_{1}$ SPAs were converted to second generation $\left(\mathrm{F}_{2}\right)$ seed production areas. Recurrent breeding helps to maintain or even increase diversity available in native populations as observed in three generations of E. urophylla in China (Lu et al., 2018). Cornelius et al. (2006) proposed management strategies to conserve genetic diversity for twenty generations of improvement in desired traits. Despite not being typical seed orchards, SPA progeny performed on par or better than commercial clones and native seedlots at diverse sites (Varghese et al., 2017). Further improvement in advanced generations will depend on management of inbreeding and co-ancestry for conserving diversity.

While classical breeding approaches focus on phenotypic selection favoring only desirable trees, it is equally important to understand the prevailing genetic diversity for effective conservation with each generation of improvement. Second generation breeding populations of E. pellita gave 10-16\% gain in North Queensland (Harwood et al.,1997) and Indonesia (Leksono et al., 2008), as there was sufficient diversity in the species (Pegg and Wang, 1994). Genetic diversity of first generation E. globulus trees in Australian national breeding program was similar to the native populations, but allelic richness was less (Jones et al., 2006). The same trend was reported by Zhang et al (2014) in first generation selections made from native populations of Pinus radiata. In Sitka Spruce, El-Kassaby (1992) reported higher heterozygosity in seed orchards than native stands. SPAs and native seedlots evaluated in this study had relatively higher number of alleles and PIC compared to CSOs, indicating the genetic quality of seed from different sources. Leite et al. (2008) reported higher diversity in SPA progenies than wild E. grandis populations and $11 \%$ lower diversity in CSO progeny compared to SPA. Offspring from clones harbor more diversity than the parent clones especially with regard to number of alleles in deployed crop (Ingvarsson and Dahlberg, 2018). Seed crops of CSOs evaluated here had $30 \%$ more alleles than ten commercial clones as the CSOs had 21 clones including ten commercially deployed clones. Genetic analysis 
of family seedlots from native provenances indicates that $80 \%$ variation occurs within populations with low genetic differentiation between populations (Zelener et al., 2005). A similar trend of higher diversity within populations was observed in this study, which shows that adequate diversity exists in second generation seed crops. Multivariate clustering using DAPC analysis grouped SPAs and CSOs in distinct groups while native seedlots and commercial clones formed indistinct groups, with some clones diverging towards CSOs. This is due to the fact that commercial clones were also represented in CSOs. A similar overlap in PNG and north Queensland provenances was reported in a genetic analysis of native E. tereticornis seedlots (Chezhian et al., 2010).

\section{Impact of fertility variation on gene diversity}

Large fertility difference is observed among trees in plantations (Bila et al., 1999) and seed orchards (Varghese et al., 2003). In general, only a proportion of individuals in a population makes a major contribution to the gamete gene pool and transmit their genes to progeny (El-Kassaby, 1995; Gonzaga et al., 2016; Tambarussi et al., 2017). Fertility variation will contribute to rapid accumulation of relatedness and inbreeding in subsequent generations (Kang et al., 2001). Seed crops from all the SPAs in the current study can be expected to have lower predicted diversity than the parent orchards due to low fertility observed even in second generation stands. Fertility was reported to vary in $\mathrm{F}_{1}$ SPAs of E. camaldulensis between a moist location $(73 \%, \psi=2)$ and dry site $(45 \%, \psi=5)$ in southern India (Kamalakannan et al., 2007). Fecundity of trees has a big impact on fertility variation as evidenced by the $\psi$ values in two CSOs (1.9 \&10.5) in the current study. Chaix et al. (2007) used fertility observations to identify imbalance in mating in Eucalyptus orchards. Though fertility was low in the current $F_{2}$ SPAs ( $26 \%)$, genetic diversity of SPA $1 \& 2$ was higher than the native seedlots. This is because these SPAs had large effective population size, and were composed of seed crops from several $F_{1}$ orchards (Varghese et al., 2009). SPA 3 had comparatively lower genetic diversity as it originated from one $F_{1}$ SPA, and had lower stocking than other SPAs. Effective population size and predicted gene diversity of CSO 1 were lower than that of SPAs, but genetic diversity was on par with SPA 3 due to low sibling coefficient and balanced contribution from most clones. Kamalakannan et al. (2016) reported low fertility variation $(\psi=1.4)$ in a clone trial (80\% contribution from $55 \%$ genotypes) of $40 \mathrm{E}$. camaldulensis clones, which is in line with the trend observed in CSO 1. Fertility variation in seed stands is generally higher than that in clonal orchards (Kang et al. 2003). Fertility variation can however have greater impact in a clonal stand compared to seedling orchard due to lower number of genotypes contributing to the gene pool. The situation can be quite alarming if fertility is skewed in a clonal stand as seen in CSO 2. Difference in fecundity and gene diversity was reported in teak CSOs ( $\Psi, 8.3$ vs 1.7$)$ across sites (Varghese et al., 2006) and between years (Nicodemus et al., 2009) in southern India.

\section{Trade-off between genetic diversity and phenotypic traits}

Gain achieved in a species will vary with phenotypic variability of traits in base population and the response of each trait to selection. Based on correlation between traits and response to selection it may be necessary to prioritize the traits for improvement. A strategy has to be evolved, to decide the selection intensity for optimal trade-off with diversity according to a breeding plan (Mora and Saavedra, 2012). Phenotypic trait expression is often influenced by genotype - environment (GxE) interaction as seen in the growth pattern of E. camaldulensis genetic material reported here. Site had a major impact on phenotypic traits of E. camaldulensis with significant GxE effects for growth and survival across three low rainfall sites, depending on the length of dry season (number of dry months per year). Survival of clones and CSO 2 seedlot was higher (60 \& $69 \%$ respectively) in a site with 3-4 months' dry spell compared to other two sites (42-51\%) experiencing 5-7 dry months (Varghese et al., 2017). Poor correlation between growth and wood traits (Hung et al., 2015) also makes it necessary to decide the intensity of selection for arriving at an optimal improvement strategy for traits of interest. Kamalakannan et al. (2016) developed a strategy to optimize gain and effective clone number in a CSO of E. camaldulensis.

Genetic diversity plays a significant role in determining adaptability and fitness of genotype to diverse environments, which is evident from the mean survival of planting stock across sites in the present study. Genetic material of low diversity (commercial clones and CSO 2 seedlot) showed higher variation in survival across three diverse sites, compared to other seedlots (Varghese et al. 2017). Survival of two SPA (1\&2) seedlots (with higher diversity) ranged from $67-72 \%$ (in site with long dry spell) to $75-88 \%$ (in site with short dry spell), which indicates the capability of these seedlots to adapt to moisture stress in different sites. Field survival of seed crops with low diversity (resulting from self-fertilization or related mating) is reported to be poor in stressed conditions (Funda and El-Kassaby, 2012). Populations with narrow genetic base like clones are more sensitive to environmental changes than those with higher genetic diversity (Bouvet et al., 2005) due to inability to compete in heterogeneous conditions (Resende et al., 2018). Li et al. (2017) reported that temperature and rainfall are the most prominent factors causing GxE differences, and deployment of genetic material across diverse sites may reduce heritability and productivity at each site. It is therefore evident from the current observations that reduction in genetic diversity affects the adaptability and productivity of genotypes in sites with diverse climatic conditions. Pulp yield is of significant economic importance to pulp industry but as seen in this study, variability in pulp yield is low in E. camaldulensis (Dehon et al., 2013), and efforts to enhance this trait will adversely affect genetic diversity and survival substantially. Hence strategies to improve absolute pulp yield by over $1 \%$ using clones and low diversity (high intensity selection) seedlots would result in reduced wood yield in multiple sites. This was evident in an evaluation of $E$. camaldulensis clones across three sites that differed in rainfall in southern India. Most of the clones 
(selected from dry locations) were superior to native provenance seed at a dry site, whereas the number of superior clones decreased in an intermediate-rainfall site, and most clones were inferior to seed sources at a high-rainfall site (Varghese et al., 2008). Since genetic diversity is essential for survival and adaptability of crop plants in diverse sites (Rao and Hodgkin, 2002) strategies to maximise gain in breeding orchards will result in loss of genetic diversity ( $\mathrm{Na}$ et al., 2015).

\section{Genetic conservation and mating system in production populations}

Seed production areas are the most common and cost-effective means of producing genetically improved seed. SPAs function as breeding populations from where new favorable recombinants can be obtained. Long term tree breeding programs need to ensure a balance between genetic gain and genetic diversity in breeding populations (Gaiotto et al., 1997). It is useful to have unpedigreed SPAs in long term breeding programs as they not only offer a quick means of improved seed in early stage of program, but also serve to reduce genetic erosion resulting from poor fertility in orchards (Kamalakannan et al., 2007). Seed production areas should have a wide genetic base like the parent $F_{1}$ orchards of the current second generation SPAs, to incorporate the genetic and trait variation available in the species (Varghese et al., 2008). High genetic diversity can be ensured in SPAs by using bulked seed from a large number of individual trees (Johnson et al., 2001). In a comparative study of teak populations, no significant difference was reported in polymorphic loci between unimproved stands and SPA (Lyngdoh et al., 2013), which is also observed in present study. Thus SPA can be effective in delivering reasonable gain without loss of genetic diversity in seed crop. Constitution of orchard and mating pattern are two factors that determine the gain and diversity obtained. This was clearly demonstrated in two $F_{2}$ SPAs (SPA 1\&2) in the current study that were originally genetic gain trials of several $F_{1}$ mixed-provenance orchards. No significant gain was obtained from the $F_{1}$ SPAs due to poor fertility and adaptability of some provenances, and lower outcrossing rate (Varghese et al., 2009) than native stands (Butcher and Williams, 2002). Hence new introduction was made from only four superior provenances (NAT) to rectify the drawback faced in first generation orchards. It is interesting to note that multilocus outcrossing rate $\left(t_{m^{\prime}}, 0.91-1.0\right)$ increased in two $F_{2}$ SPAs (SPA 1\&2) compared to a high fertility $F_{1}$ SPA $\left(t_{m^{\prime}} 0.86\right.$, Varghese et al., 2009). Outcrossing rate may differ drastically between populations as observed in Irian Jaya $(<50 \%)$ and Queensland (73\%) populations of E. pellita (House and Bell, 1996). It is therefore evident that genetic gain and diversity can be obtained from an orchard only if the best provenances are used to produce outcrossed seed suited to the site. Preferential mating between different provenances (Jones et al., 2008) or adjoining trees (Gonzaga et al., 2016) can result in non-random mating and genetic drift.

In the present study outcrossing rate was generally high in SPAs $1 \& 2$ and CSO 1, as reported in a productive E. grandis orchard $\left(t_{m}=0.97\right)$ by Chaix et al. (2003). Reduction in genetic gain in bole volume (55\%) and seedling growth (9.5\%) has been reported (Chaix et al., 2010) with inbreeding (selfing and related mating) in E. grandis orchards (Gonzaga et al., 2016). Identification and culling of inbred seedlings using molecular markers is proposed to reduce productivity loss due to inbreeding (Chaix et al., 2010). In this study, self-pollination was detected in one seedlot each (low $t_{m}$ values) of SPA 3 and CSO 2 , which reduced the diversity and survival of progeny. Related mating $\left(t_{m}-t_{s}\right)$ was low in most families except one family each of CSO 1 and SPA 2, which probably got carried over from correlated mating (22\%) reported in parent $F_{1}$ SPA (Varghese et al., 2009). Correlated mating in $F_{2}$ progeny $(0.024-0.096)$ was generally less than the mean values reported by Gonzaga et al. (2016) in E. camaldulensis SSO $\left(r_{p}=0.185\right)$ and Bezemer et al. (2016) in E. caesia $\left(r_{p}=0.136\right)$. It is quite evident from the current study that genetic diversity is a prerequisite for pure species improvement, as adaptability is compromised with reduction in number of alleles in the population. In E. gracilis, a preferentially outcrossed species, Breed et al. (2014) observed greater fitness in populations originating from multiple paternities. Decline in genetic diversity can have implications on adaptability of trees to withstand biotic and abiotic stresses under varying climatic conditions (Porth and El-Kassaby, 2014). Hence a conservative strategy like SPA is quite effective to ensure sustainability in terms of adaptability to different sites.

\section{Management of seed orchards}

Fertility variation can be high in an orchard having large number of genotypes, especially in early stages of domestication of a species. Maintaining adequate number of pollen parents, and constant seed collection from superior trees will help to reduce genetic drift. Constant seed collection from a certain proportion of trees can increase diversity of seed crop (Kang et al., 2001), as inferred from predicted GD in CSO 2. The major reason for genetic diversity difference between SPAs is that SPAs $1 \& 2$ (developed from genetic gain trials) had more grandparents than SPA 3. The genetic gain trials had 25 grandparents each from five first generation orchards (Varghese et al., 2009) whereas SPA 3 had a base of only 25 grandparents from one $F_{1}$ SPA. Thinning to remove inferior trees has further reduced the genetic base which has been further narrowed down, as only $26 \%$ trees contributed to the gene pool. Danusevicius and Lindgren (2010) recommended restriction in number of parent trees per grandparent in an orchard for sustaining diversity and gain based on heritability of the trait.

Restriction in number of trees per family enables retention of alleles and high effective population size to sustain diversity in seed crop (Silva et al., 2018). When effective population size is low, relatedness increases giving little option for selection between families. High fertility variation coupled with low effective population size can result in reduced outcrossing rate as evident from low $t_{m}$ value in one family each of SPA 3 and $\mathrm{CSO} 2$. Low effective population size was reported in an $E$. tereticornis SSO (Varghese et al., 2003) due to high fecundity in a small proportion of trees, as seen in CSO 2. Johnson et al. (2001) suggested that 200 outstanding selections would be enough 
to maintain gain in breeding programs, but to conserve diversity higher number of parent trees (400-1000) is desirable, as observed in SPA 1\&2. Diversity in terms of number of families represented would be a prerequisite for advanced generation breeding; and restriction in selection from each family is often practiced to ensure that alleles are conserved in each generation (Silva et al., 2018). Constant seed collection is also a similar strategy as evidenced by only $1 \%$ reduction in number of alleles in CSO 2 compared to CSO 1 (despite big difference in fecundity) whereas there was $9 \%$ difference in alleles per locus between SPA 2 and SPA 3. This trend is evident from the high self-pollination $\left(t_{m}=0.69\right)$ rate observed in one family of SPA 3 , which is close to the upper limit of self-pollination (0-36\%) reported in E. grandis populations (Jones et al., 2008). Predicted diversity based on fertility observations in orchards gives a good estimate of the expected heterozygosity and group coancestry in seed crop (Park et al., 2017). This is confirmed by the high positive correlation between $H_{e}$ and predicted gene diversity, and a similar trend in allelic richness, in SPAs and CSOs. The impact of genetic diversity on phenotypic traits (especially survival rate) implies that orchards have to be carefully monitored to produce seed crop of desired quality.

\section{Deployment of hybrids}

Interspecific hybrids of a few parent trees had higher survival and pulp yield due to higher diversity and PIC, despite having lower number of alleles than SPA seedlots of E. camaldulensis. A similar trend was reported by Larcombe et al. (2014) in native stands of $E$. camaldulensis where putative interspecific hybrids of a few parent trees had higher heterozygosity than pure species, despite having lower number of alleles. Interspecific hybrids are widely deployed worldwide as they have the capacity to combine desirable traits of different species and provide several benefits over pure species. Zhu et al (2017) reported better growth and survival of E. urophylla $\times$ E. camaldulensis hybrids than pure species in China, which is in line with the results of current study. Gardner et al. (2007) reported $2 \%$ higher pulp yield in eucalypt hybrids (E. grandis $\times$ E. camaldulensis) than E. tereticornis in a low rainfall site in South Africa, as observed in this study. Retief and Stanger (2009) observed that $60 \%$ of total genetic variance in hybrids (E. grandis x E. urophylla) was caused by dominance effects with large specific combining effects. A similar trend was observed in this study where four interspecific hybrid combinations of $E$. camaldulensis $x E$. urophylla were superior to pure species in growth and pulp yield out of 16 combinations tested (Kamalakannan et al., 2011). Hybrids are not grown in a big way in India due to low adaptability in marginal sites. Hybrids were evaluated in the current study only in two sites along with other E. camaldulensis genetic material, but not in the third low productivity site. Hybrids tested in these two sites may not suite the arid low productivity site as eucalypts vary in water stress tolerance depending on rainfall at the site from which they originate (Arndt et al., 2014). Performance of hybrids vary with site as observed by Luo et al. (2012) in China where E. tereticornis based hybrids had higher survival compared to E. grandis $x E$. urophylla hybrids. A dedicated hybrid (E. camaldulensis $\times$ E. urophylla / E. pellita) breeding program has been initiated to enhance wood and pulp yield in medium rainfall regions in southern India. When GxE interaction is quite high as observed by Gardner et al. (2007), separate zones may have to be earmarked for deploying suitable hybrids for each region to get maximum genetic gain (Hardner et al., 2011).

\section{Summary and implications in eucalypt breeding}

Genetic diversity and phenotypic traits were evaluated in second generation SPAs, clonal seed orchards and commercial clones of E. camaldulensis, in relation to native Australian provenances and interspecific hybrids at diverse sites. Fertility variation and drift in $\mathrm{F}_{1}$ parent orchards led to genetic erosion from the base population of 11 native provenances of $E$. camaldulensis. Low fertility was recorded in $\mathrm{F}_{2}$ SPAs also, but number of alleles and genetic diversity were higher than native provenances in two SPAs (SPA 1-2), that originated from multiple $F_{1}$ orchard seedlots. Seed crops may vary in constitution depending on fertility of parent trees in orchards at diverse sites. Heterozygosity and allelic diversity are greatly influenced by effective population size which is used to estimate gene diversity, as a surrogate for genetic diversity in seed orchards (Funda et al., 2009). Mating was close to random in CSO $1(\psi=1.95)$ but predicted $G D$ and number of alleles were less than the SPAs due to low $N_{s}$. During domestication it is important to ensure that heterozygosity prevailing in native stands, is enhanced or at least maintained in subsequent generations. Despite fertility variation and drift, large number of genetically unique individuals in SPAs $1 \& 2$ ensured high effective population size and outcrossing rate. Conservation of genetic diversity is of great significance in achieving productivity improvement in $E$. camaldulensis. Reduction in genetic diversity is manifested in poor overall fitness and survival of progeny. Gene diversity computed from fertility observations had high correlation with genetic diversity of seed crop estimated using molecular markers. The study points out that breeding programs for improving growth and wood traits should maintain high effective population size in orchards to ensure adequate diversity. Fertility variation can be controlled in orchards (especially CSO) using management techniques like constant seed collection to enhance gene diversity. Seed production areas with high effective population size and high outcrossing rate conserve more alleles and diversity in advanced generations than clonal seed orchards and clones of E. camaldulensis. Since the proportion of genetic diversity occurring within populations is high, a low input breeding strategy (SPA) which can accommodate large number of unrelated trees would give higher overall benefit in terms of both genetic and trait diversity. Short term strategies to enhance gain in high input breeding efforts like CSOs should ensure high fertility and effective population size for adaptability of progeny to multiple sites. Inbreeding from selfing, related mating and correlated paternity can reduce productivity in seed crops. Parent trees with high selfing or related mating can be identified for culling, or elimination in seed collection using fertility data and molecular markers. Self-pollination was 
detected in low diversity seed crops of SPA 3 and CSO 2. Genetic diversity and survival of progeny are influenced by the number of effectively contributing parent trees and mating system in orchard. This study reveals that fertility based gene diversity estimates can be used to predict seed quality and progeny performance, as evidenced by molecular markers and phenotypic traits. Since pulp yield is negatively correlated with genetic diversity and field survival, scope of improving this trait is limited in pure species due to low variability and large site effects. Interspecific hybrids of E. camaldulensis with E. urophylla or $E$. pellita can be deployed, after screening for adaptability to different sites, as they have more diversity, higher growth, and pulp yield than $E$. camaldulensis clones and seed lots.

\section{References}

Arndt S, Sanders G, Hirsch M (2014) Hydraulic and ecophysiological traits related to tree drought mortality are linked to the aridity of the environment in eucalypts. Int Forest Rev 16(5): 236

Bezemer N, Krauss SL, Phillips RD, Roberts DG, Hopper SD (2016) Paternity analysis reveals wide pollen dispersal and high multiple paternity in a small isolated population of the bird-pollinated Eucalyptus caesia (Myrtaceae). Heredity (2016) 117, 460-471. https://doi.org/10.1038/hdy.2016.61

Bila AD, Lindgren D, Mullin TJ (1999) Fertility variation and its effect on diversity over generations in a teak plantation (Tectona grandis L.f) Silvae Genet 48:109-114.

Bouvet JM, Vigneron P, Saya A (2005) Phenotypic plasticity of growth trajectory and ontogenic allometry in response to density for Eucalyptus hybrid clones and families. Ann Bot 96: 811-821. https://doi.org/10.1093/aob/mci231

Bouvet JM, Saya A, Vigneron P (2009) Trends in additive, dominance and environmental effects with age for growth traits in Eucalyptus hybrid populations, Euphytica, 165 : 35-54. https://doi.org/10.1007/s10681-008-9746-x

Breed MF, Christmas MJ, Lowe AJ (2014) Higher levels of multiple paternities increase seedling survival in the long-lived tree Eucalyptus gracilis. PLoS ONE 9(2):1-9. https://doi.org/10.1371/journal.pone.0090478

Burgess IP, Williams ER, Bell JC, Harwood CE, Owen JV (1996) The effect of outcrossing rate on the growth of selected families of Eucalyptus grandis. Silvae Genet 45 (2-3):97-100

Butcher PA, Williams ER (2002) Variation in outcrossing rates and growth in Euca lyptus camaldulensis from the Petford Region, Queensland; evidence of outbreeding depression. Silvae Genet 51:6-12

Chezhian P, Yasodha R, Modhumita Ghosh (2010) Genetic diversity analysis in a seed orchard of Eucalyptus tereticornis. New For. 40: 85-99. https://doi.org/10.1007/s11056-009-9184-1

Chaix G, Gerber S, Razafimaharo V, Vigneron P, Verhaegen D, Hamon S (2003) Gene flow estimation with microsatellites in a Malagasy seed orchard of Eucalyptus grandis. Theor Appl Genet 107:705-712. https://doi.org/10.1007/s00122-003-1294-0

Chaix G, Vigneron P, Razafimaharo V, Hamon S (2007) Are phenological observations sufficient to estimate the quality of seed crops from a Eucalyptus grandis open-pollinated seed orchard? consequences for seed collections. New For 33: 41-52. https://doi.org/10.1007/s11056-006-9012-9

Chaix G, Vigneron P, Razafimaharo V, Hamon S (2010) Improved management of Malagasy Eucalyptus grandis seed orchards using microsatellites and paternity assessment. J Trop For Sci 22(3): 271-280.

Cornelius JP, Clement CR, Weber JC, Sotelo-Montes C, van Leeuwen J, Ugarte-Guerra LJ, Ricse-Tembladera A, Arevalo-Lopez L (2006). The trade-off between genetic gain and conservation in a participatory improvement programme: the case of peach palm (Bactris gasipaes Kunth). Forests, Trees and Livelihoods, 2006, Vol. 16, pp. 17-34. https://doi.org/10.1080/14728028.2006.9752543
Danusevicius D, Lindgren D (2010) Efficiency of breeding strategy where grandparents - but not parents - contribute equally to the breeding population. Ann. For. Sci. 67 (2010) 404. https://doi.org/10.1051/forest/2009124

Davidson J (1998) Domestication and breeding programme for Eucalyptus in the Asia-Pacific region. UNDP/FAO Regional Project on Improved Productivity of Man-Made Forests through Application of Technological Advances in Tree Breeding and Propagation (FORTIP), Philippines. 252p.

Dehon G, Resende S, Resende M, Assis T (2013) A roadmap to eucalyptus breeding for clonal forestry. In: Fenning TM (ed) Challenges and opportunities for the world's forests in the 21st century. Springer, Dordrecht, pp 394-424.

Doran JC, Pinyopusarerk K, Arnold R, Harwood CE (1996) Breeding Plan for Eucalyptus camaldulensis in Tamil nadu. UNDP/FAO Regional Project on Improved Productivity of Man Made Forests through Application of Technical Advances in Tree Breeding and Propagation (RAS/91/004 - FORTIP), FAO, Los Banos, Phillipines, 40p.

El-Kassaby YA (1992). Domestication and genetic diversity - should we be concerned? Forest Chron 68(6): 687- 700. https://doi.org/10.5558/tfc68687-6

El-Kassaby YA (1995) Evaluation of tree-improvement delivery system: factors affecting genetic potential. Tree Physiol 15:545-550. https://doi.org/10.1093/treephys/15.7-8.545

Funda, T, El-Kassaby YA (2012) Seed orchard genetics. CAB Reviews 7(13): 1-23. https://doi.org/10.1079/pavsnnr20127013

Funda T, Lstibůrek M, Lachout P, Klápště J, El-Kassaby YA (2009) Optimization of combined genetic gain and diversity for collection and deployment of seed orchard crops. Tree Genet Genomes 5: 583-593. https://doi.org/10.1007/s11295-009-0211-3

Gaiotto FA, Bramucci M, Grattapaglia D (1997) Estimation of out-crossing rate in a breeding population of Eucalyptus urophylla with dominant RAPD and AFLP markers. Theor Appl Genet 95:842-849. https://doi.org/10.1007/s001220050634

Gardner RAW, Little KM, Arbuthnot A (2007) Wood and fibre productivity potential of promising new eucalypt species for coastal Zululand, South Africa. Aust Forestry 70: 35-47. https://doi.org/10.1080/00049158.2007.10676261

Gonzaga JMS, Manoel RO, Sousa ACB, Sousa AP, Moraes MLT, Freitas MLM, Sebbenn AM (2016) Pollen contamination and non-random mating in a Eucalyptus camaldulensis Dehnh seedling seed orchard, Silvae Genet 65(1): 1-11. https://doi.org/10.1515/sg-2016-0001

Griffin AR (2014) Clones or improved seedlings of Eucalyptus? Not a simple choice. Int Forest Rev 16:216-224. https://doi.org/10.1505/146554814811724793

Hardner C, Dieters M, DeLacy I, Neal J, Fletcher S, Dale G, Basford K (2011) Identifying deployment zones for Eucalyptus camaldulensis $\times E$. globulus and $\times E$. grandis hybrids using factor analytic modelling of genotype by environment interaction. Aust Forestry 74(1):30-35. https://doi.org/10.1080/00049158.2011.10676343

Harwood CE, Nikles DG, Pomroy PC, Robson KW (1997) Genetic improvement of E. pellita in North Queensland, Australia. In: Proceedings of the IUFRO Conference on Silviculture and improvement of eucalypt, Salvador, pp 219-226. Hendre PS, Kamalakannan R, Varghese M (2012) High-throughput and parallel SNP discovery in selected candidate genes in Eucalyptus camaldulensis using Illumina NGS platform. Plant Biotech J 10:646-656. https://doi.org/10.1111/j.1467-7652.2012.00699.x

Hou YC, Yan ZH, Wei YM, Zheng YL (2005) Genetic diversity in barley from west China based on RAPD and ISSR analysis. Barley Genetics Newsletter 35:9-22

Hung TD, Brawner JT, Meder R, Lee DJ, Southerton S, Thinh HH, Dieters MJ (2015) Estimates of genetic parameters for growth and wood properties in Eucalyptus pellita F. Muell. to support tree breeding in Vietnam. Ann For Sci 72:205-217. http://dx.doi.org/10.1007/s13595-014-0426-9

House APN, Bell JC (1996) Genetic diversity, mating system and systematic relationships in two red mahoganies, Eucalyptus pellita and E. scias. Aust J Bot 44(2):157-174. https://doi.org/10.1071/bt9960157

Ingvarsson PK, Dahlberg H (2018) The effects of clonal forestry on genetic diversity in wild and domesticated stands of forest trees, Scand J For Res, https://doi.org/10.1080/02827581.2018.1469665

Ivetić V, Devetaković J, Nonić M, Stanković D, Šijačić-Nikolić M (2016) Genetic diversity and forest reproductive material - from seed source selection to planting. iForest 9:801-812. https://doi.org/10.3832/ifor1577-009 
Johnson R, St. Clair B, Lipow S (2001) Genetic conservation in applied tree breeding programs. In: Bart A, Thielges BA, Sastrapradja SD, Rimbawanto A (eds) Proceedings of the ITTO Conference on In Situ and Ex Situ Conservation of Commercial Tropical Trees, pp. 215-230. ITTO, Yokohama, Japan.

Jombart T (2008) adegenet: an R package for the multivariate analysis of genetic markers. Bioinformatics 24:1403-1405.

https://doi.org/10.1093/bioinformatics/btn129

Jones TH, Steane DA, Jones RC, Pilbeam D, Vaillancourt RE, Potts BM (2006) Effects of domestication on genetic diversity in Eucalyptus globulus. Forest Ecol Manag 234(1-3): 78-84. https://doi.org/10.1016/j.foreco.2006.06.021

Jones ME, Shepherd M, Henry R, Delves A (2008) Pollen flow in Eucalyptus gran dis determined by paternity analysis using microsatellite markers. Tree Genet Genomes (2008) 4:37-47. https://doi.org/10.1007/s11295-007-0086-0

Kalinowski ST, Taper ML, Marshall TC (2007) Revising how the computer program CERVUS accommodates genotyping error increases success in paternity assignment. Mol Ecol 16:1099-1106. https://doi.org/10.1111/j.1365-294X.2007.03089.x

Kamalakannan R, Suraj PG, Arutselvan T, Varghese M (2011) Early growth perfor mance and wood properties of Eucalyptus interspecific hybrids at coastal and inland sites in southern India. In: IUFRO Conference on improvement and Culture of Eucalyptus, Porto Seguro, Brazil. Proceedings (ed.) Goncalves JLdeM, Stape JL, Grattapaglia D, Voigtlaender M. Piracicaba: ESALQ, 2011. 461-463p.

Kamalakannan R, Varghese M, Suraj PG, Arutselvan T (2016) Options for converting a clone trial of Eucalyptus camaldulensis into a clonal seed orchard considering gain, fertility and effective clone number. J For Res 27(1):51-57. https://doi.org/10.1007/s11676-015-0169-y

Kamalakannan R, Varghese M, Lindgren D (2007) Fertility variation and its implications on relatedness in seed crops in seedling seed orchards of Eucalyptus camaldulensis and E. tereticornis. Silvae Genet 56:253-259. https://doi.org/10.1515/sg-2007-0036

Kamalakannan R, Varghese M, Chezhian P, Ghosh M, Lindgren D (2009) Fertility variation and gene diversity in seed crops of Eucalyptus and Casuarina seedling seed orchards in southern India. In: Proceedings Seed Orchards Conference, Jeju, 8-11 September 2009. p 35.

Kang KS, Lindgren D, Mullin TJ (2001) Prediction of genetic gain and gene diversity in seed orchards crops under alternative management strategies. Theor Appl Genet 103(6-7):1099-1107.https://doi.org/10.1007/s001220100700

Kang KS, Bila AD, Harju AM, Lindgren D (2003). Estimation of fertility variation in forest tree populations. Forestry 76(3):329-344. https://doi.org/10.1093/forestry/76.3.329

Kang KS, Lindgren D (1999) Fertility variation among clones of Korean pine and its implications on seed orchard management. For Genet 6:191-200.

Krishnakumar N, Sivakumar V, Anandalakshmi R (2014) Eucalypt improvement in southern India. In: Bhojvaid PP, Kaushik S, Singh YP, Kumar D, Thapliyal M, Barthwal S (eds) Eucalypts in India. Forest Research Institute, Dehra Dun, pp 139-148.

Kulkarni HD (2014) Eucalypt Improvement at ITC. In: Bhojvaid PP, Kaushik S, Singh YP, Kumar D, Thapliyal M, Barthwal S (eds) Eucalypts in India. Forest Research Institute, Dehra Dun, pp 149-184.

Larcombe MJ, Vaillancourt RE, Jones RC, Potts BM (2014) Assessing a bayesian approach for detecting exotic hybrids between plantation and native eucalypts, International Journal of Forestry Research, vol. 2014, Article ID 650202, 13 pages, 2014. https://doi.org/10.1155/2014/650202.

Lefevre F (2004) Human impacts on forest genetic resources in the temperate zone: An updated review. For Ecol Manag197: 257-271. https://doi.org/10.1016/j.foreco.2004.05.017

Leite SMM, Mori ES, do Valle CF, Bonine CAV, Marino CL (2008) RAPD analysis of genetic variability in a multiprovenance base population of Eucalyptus grandis Hill ex Maiden. R. Árvore, Viçosa-MG, 32(6): 961-967. https://doi.org/10.1590/s0100-67622008000600001

Leksono B, Kurinobu S, Ide Y (2008) Realised genetic gains observed in second generation seedling seed orchards of Eucalyptus pellita in Indonesia. J For Res 13:110-116. https://doi.org/10.1007/s10310-008-0061-0

Li Y, Suontama M, Burdon RD, Dungey HS (2017) Genotype by environment interactions in forest tree breeding: review of methodology and perspectives on research and application. Tree Genet Genomes13: 60 - 77. https://doi.org/10.1007/s11295-017-1144-X
Libby WJ, McCutchan BG, Millar CI (1981) Inbreeding depression in selfs of redwood. Silvae Genet 30:15-25.

Lindgren D (2003) Low-input tree breeding strategies. In: Wei RP, Xu D (eds) Eucalyptus plantations-research, management and development. World Scientific, Singapore, pp 149-166

Lindgren D, Mullin TJ (1998) Relatedness and status number in seed orchard crops. Can. J. For. Res. 28: 276-283. https://doi.org/10.1139/x97-217

Lindgren D, Gea L, Jefferson P (1996) Loss of genetic diversity monitored by status number. Silvae Genet 45:52-59.

Lu W, Arnold RJ, Zhang L, Luo J (2018) Genetic diversity and structure through three cycles of a Eucalyptus urophylla S.T.Blake breeding program. Forests 9 : 372-392.https://doi.org/10.3390/f9070372

Luo JZ, Arnold RJ, Cao JG, Lu WH, Ren SQ, Xie YJ, Xu LA (2012) Variation in pulp wood traits between eucalypt clones across sites and implications for deployment strategies. J Trop For Sci 24(1): 70-82.

Lyngdoh N, Joshi G, Ravikanth G, Vasudeva R, Uma Shaanker R (2013) Changes in genetic diversity parameters in unimproved and improved populations of teak (Tectona grandis L.f.) in Karnataka state, India. J Genet 92(1):141-145. https://doi.org/10.1007/s12041-013-0226-2

Mora F, Saavedra J (2012) Combining genetic gain and diversity under an individual selection method in a selected provenance of Eucalyptus cladocalyx. Plant Breeding, Genetic and Genetic Resources Cien. Inv. Agr. 39(1):177-184. https://doi.org/10.4067/s0718-16202012000100014

Nagabhushana K, Prasad SH, Rajkumar R (2017) Intra and intergeneric transferable gene-derived orthologous microsatellite markers in Eucalyptus and Corymbia species. J For Res 22 (1), 65-68. https://doi.org/10.1080/13416979.2016.1262726

Na SJ, Lee HS, Han SU, Park JM, Kang KS (2015) Estimation of genetic gain and diversity under various genetic thinning scenarios in a breeding seed orchard of Quercus acutissima. Scand J For Res. 30: 377-38. https://doi.org/10.1080/02827581.2015.1018936

Nicodemus A, Varghese M, Nagarajan B, Lindgren D (2009) Annual fertility variation in clonal seed orchards of teak (Tectona grandis L.f.) and its impact on seed crop. Silvae Genet 58: 85-93. https://doi.org/10.1515/sg-2009-0011

Park JM, Kwon SH, Lee HJ, Na SJ, El-Kassaby YA,Kang KS (2017) Integrating fecundity variation and genetic relatedness in estimating the gene diversity of seed crops: Pinus koraiensis seed orchard as an example. Can J For Res 47:366-370. https://doi.org/10.1139/cjfr-2016-0223

Peakall R, Smouse PE (2012) GenAIEx 6.5: genetic analysis in Excel. Population genetic software for teaching and research - an update. Bioinformatics 28 , 2537-2539. https://doi.org/10.1093/bioinformatics/bts460

Pegg RE, Wang GX (1994) Results of Eucalyptus pellita trials at Dongmen, China. In: Brown, A.G. (ed.) Australian tree species research in China: Proceedings of and international workshop held at Zhangzhou, Fujian Province, PRC, 2-5 November, ACIAR Proceedings No. 48. ACIAR, Canberra, pp.108-115.

Poltry SNM, Zelener M, Traverso JR, Gelid P, Hopp HE (2003) Selection of a seed orchard of Eucalyptus dunnii based on genetic diversity criteria calculated using molecular markers. Tree Physiol 23: 625-632. https://doi.org/10.1093/treephys/23.9.625

Porth I, El-Kassaby YA (2014) Assessment of the genetic diversity in forest tree populations using molecular markers. Diversity 2014 (6): 283-295. https://doi.org/10.3390/d6020283

Rao VR, Hodgkin T (2002) Genetic diversity and conservation and utilization of plant genetic resources. Plant Cell Tiss Org 68: 1-19.

Resende RT, Soares AAV, Forrester DI, Marcatti GE, dos Santos AR, Takahashi EK, Silva FF, Grattapaglia D, Resende MDV, Leite HG (2018) Environmental uniformity, site quality and tree competition interact to determine stand productivity of clonal Eucalyptus. Forest Ecol Manag 410: 76-83. https://doi.org/10.1016/j.foreco.2017.12.038

Retief ECL, Stanger TK (2009) Genetic parameters of pure and hybrid populations of Eucalyptus grandis and E. urophylla and implications for hybrid breeding strategy, South For 71(2): 133 - 140. https://doi.org/10.2989/sf.2009.71.2.8.823

Ritland K (2002) Extensions of models for the estimation of mating systems using $\mathrm{n}$ independent loci. Heredity 88 (4):221-228. https://doi.org/10.1038/sj.hdy.6800029

Silva PHM, Brune A, Pupin S, Moraes MLT, Sebbenn AM, de Paula RC (2018) Maintenance of genetic diversity in Eucalyptus urophylla S. T. Blake populations 
with restriction of the number of trees per family. Silvae Genet 67:34 - 40. https://doi.org/10.2478/sq-2018-0005

Sumathi M, Yasodha R (2014) Microsatellite resources of Eucalyptus: current status and future perspectives. Bot Stud 55:73-88. http://www.as botanicalstudies.com/content/55/1/73

Tambarussi EV, Boshier D, Vencovsky R, Menezes Freitas ML, Sebbenn AM (2017) Inbreeding depression from selfing and mating between relatives in the Neotropical tree Cariniana legalis Mart. Kuntze. Conservation Genetics 18(1): 225-234. https://doi.org/10.1007/s10592-016-0896-4

Varghese M, Nicodemus A, Nagarajan B, Subramanian K (2000) Hybrid breakdown in Mysore gum and need for genetic improvement of Eucalyptus camaldulensis and E. tereticornis. In: Hybrid Breeding and Genetics of Forest Trees, Proceedings QFRI/CRC-SPF Symposium, 9-14 April 2000, Noosa, Queensland, Australia. (Compiled by Dungey, H. S., Dieters, M. J. and Nikles, D. G.) Department of Primary Industries, Brisbane, pp 519-525

Varghese M, Ravi N, Son SG, Lindgren D (2003) Variation in fertility and its impact on gene diversity in a seedling seed orchard of Eucalyptus tereticornis In: Wei RP, Xu D (eds) Eucalyptus Plantations - Research, Management and Development. World Scientific, Singapore, pp 111-126. https://doi.org/10.1142/97898127045040010

Varghese M, Harwood CE, Bush DJ, Baltunis B, Kamalakannan R, Suraj PG, Hegde D, Meder R (2017) Growth and wood properties of natural provenances, local seed sources and clones of Eucalyptus camaldulensis in southern India: implications for breeding and deployment. New For. 48(1):67-82. https://doi.org/10.1007/s11056-016-9556-2

Varghese M, Harwood CE, Hegde R, Ravi N (2008) Evaluation of provenances of Eucalyptus camaldulensis and clones of E. camaldulensis and E. tereticornis at contrasting sites in southern India. Silvae Genet 57:170-179. https://doi.org/10.1515/sg-2008-0026

Varghese M, Kamalakannan R, Harwood CE, Lindgren D, McDonald MW (2009) Changes in growth performance and fecundity of Eucalyptus camaldulensis and E. tereticornis during domestication in southern India. Tree Genet Genomes 5(4): 629-640. https://doi.org/10.1007/s11295-009-0215-z

Varghese M, Nicodemus A, Nagarajan B, Lindgren D (2006) Impact of fertility variation on gene diversity and drift in two clonal seed orchards of teak (Tectona grandis Linn. f.). New For. 31: 497-512. https://doi.org/10.1007/s11056-005-2178-8

White DA, McGrath JF, Ryan MG, Battaglia M, Mendham DS, Kinal J, Downes GM, Crombie DS, Hunt ME (2014) Managing for water-use efficient wood production in Eucalyptus globulus plantations. For Ecol Manag 331:272-280. https://doi.org/10.1016/j.foreco.2014.08.020

Williams CG, Savolainen O (1996) Inbreeding depression in conifers: Implications for breeding strategy. Forest Science 42:102-117.

Zhang L, Huanqiong N, Gapare WJ, Dillon SK, Li X, Wu HX (2014) Comparison of allelic diversity between native gene resource plantings and selections in open-pollinated progeny test of Pinus radiata D. Don. Silvae Genet 63(5): 213-221.https://doi.org/10.1515/sg-2014-0027

Zelener N, Poltri SN, Bartoloni N, Lopez CR, Hopp HE (2005) Selection strategy for a seedling seed orchard design based on trait selection index and genomic analysis by molecular markers: a case study for Eucalyptus dunnii. Tree Physiol 25:1457-1467. https://doi.org/10.1093/treephys/25.11.1457

Zhu Y, Wu S, Xu J, Lu Z, Li G, Hu Y, Yang X, Bush D (2017) Genetic parameters for growth traits and stem-straightness in Eucalyptus urophylla $\times$ E. camaldulensis hybrids from a reciprocal mating design. Euphytica (2017) 213:142. https://doi.org/10.1007/s10681-017-1923-3 